\title{
12.B Economic Dynamics in the Arsakid Empire
}

\section{Introduction}

\section{I.1 Arsakids and the Hellenistic and Post-Achaemenid Worlds}

This brief consideration of the economic processes in the Arsakid Empire picks up where the previous chapter on hypotheses concerning processes and patterns in the Hellenistic world ends. It considers the Arsakid Empire, looking at both the core territory stretching across Mesopotamia and Iran, and the halo of polities that has increasingly come to be understood as the "Parthian Commonwealth," including both smaller and larger vassal kingdoms along the flanks of the Arsakid heartland. ${ }^{1}$ A synthetic elucidation of the dynamic processes by which the Arsakid Empire came to incorporate these diverse local spaces on an economic level - or how the local spaces reacted to the new forms of Arsakid control - lies out of reach of current scholarship. The available documentary, archaeological, and historical evidence is pointillistic and often internally inconsistent, problems that were discussed at more length in other chapters here as well as in our previous volume. ${ }^{2}$

The attempt in what follows is rather to consider how the general framework laid out by von Reden with respect to the Hellenistic world can be applied in the context of the Arsakid Empire, looking for moments of continuity, rupture, or gradual divergence. A fundamental question here is whether and in what ways the economy of the Arsakid Empire came to function as an "overarching fiscal-military" regime of the type described by von Reden for the Hellenistic world. ${ }^{3}$ The explicit comparison of the Hellenistic and Arsakid Empires is not intended to suggest that the Arsakid world should be understood fundamentally, or even primarily, as a product of the Hellenistic world. However much the rise of the Arsakid dynasty in the third century BCE was predicated on preconditions in the Hellenistic Near East, and however much once-Seleukid territory the Arsakids came to control over the course of second and first centuries BCE, the logic of their empire developed atop a wide range of cultural substrata - drawing most obviously on pre-Seleukid Achaemenid models of the Iranian Plateau (which were also a part of the Hellenistic legacy), but also on patterns among the Parni, from whom the dynasty emerged. ${ }^{4}$ At the

1 On the concept of the Parthian Commonwealth, see de Jong 2013. For alternative nomenclature, including that of a "network empire," Gregoratti 2019, 53.

2 See Taasob, ch. 3.B and 8.B, this volume; Fabian, vol. 1, ch. 7, Wiesehöfer vol. 1, ch. 11.

3 Von Reden, ch. 12.A, this volume.

4 The question of the impact of these Parni, or more broadly speaking of mobile pastoralist influences on later Parthian elite culture have been long debated, see, e.g., Wolski 1993; Olbrycht 2003,

\footnotetext{
○ Open Access. (C) 2022 Lara Fabian, published by De Gruyter. (cc)BY-NC-ND This work is licensed under the Creative Commons Attribution-NonCommercial-NoDerivatives 4.0 License. 
same time, the role of Graeco-Macedonian elite individuals and the behavioral norms inherited from this community, diminished over time. ${ }^{5}$ The Arsakid Empire, furthermore, was not static, but continued to evolve along its own path over the roughly four centuries of Arsakid control, incorporating new approaches as it grew. ${ }^{6}$

It is precisely because of this complexity that considering Arsakid developments in light of those in the Hellenistic world is helpful. The contrastive approach allows us to identify particular institutional, social, and spatial factors within the Arsakid world that shaped regional development in this central space. Such an approach furthermore focuses attention on challenging phenomena such as growth and intensification that are seldom discussed in the Arsakid context due to the uneven evidentiary basis, but which nevertheless remind us to think of Iran and southwestern Asia as dynamic spaces, and the economic life of the Arsakid world as a matter in flux.

\section{I.2 Models and Implicit Narratives}

Explicit work on the economic history of the Arsakid world remains relatively rare, in spite of the centrality of the discipline of numismatics in studies of this space. ${ }^{7}$ Filling the void left by the absence of such work is an underlying, tenacious perception of the Arsakid world's centrality in global trade systems, in which they have been seen as alternatively a force blocking the establishment of transregional networks, or conversely as the facilitators of such networks. However important trade may have been in the larger Arsakid systems, such approaches run the risk of decentering the object of inquiry itself - the Arsakids. Instead, they place the conceptual weight on Arsakid interaction with external forces of market-based international supply and demand pulling products from Rome to China, mechanisms which themselves are not in keeping with our understanding of economic forces in our period of inquiry.

Rather than starting with questions of connectivity, the present discussion begins with an examination of the structuring factors of the Arsakid Empire that contributed to patterns of production, consumption, and distribution within Arsakid

2013; Hauser 2005, 2006. The Parni themselves were likely related to a larger mobile pastoralist confederation active around the Caspian coast, Olbrycht 2003, 71-72; 2015, 257-258; 2019.

5 Which is not to argue that they disappeared, as the repeated invocations of philhellenism among Arsakid dynasts itself attests. Beyond such declarations, there is also compelling evidence for longstanding court contacts between Arsakid dynasts and their Hellenistic neighbors, and for the explicit role of Greek learning at the Arsakid court, e.g., material discussed in Wiesehöfer 2015; as well as Dąbrowa 1998; 2013; and, e.g., Schlude and Overman 2017.

6 On changing strategies of rule from a representational perspective, Shayegan 2011.

7 Exceptions include Lukonin 1983 as well as more recent works mostly focusing on Babylonia, including van der Spek 2014, 1998; van der Spek and Leeuwen 2014; Pirngruber 2017. 
space, with particular attention to factors that von Reden has identified as central to the question of growth in the Hellenistic world, namely expanding urban systems, growing militaries, and the related phenomenon of agricultural intensification necessary to sustain these activities. I then move on to consider evidence for points of transformation within the Arsakid system. For, despite the many institutional continuities noted by von Reden above and discussed by Taasob in ch. 3.A, developments within the sociopolitical and economic sphere under the Arsakids eventually led to the establishment of a radically new imperial geography. The final section, by way of conclusion, picks up on the question of imperial geography and on the distinctive patterns of connectivity and network opportunities that grew across this central expanse.

\section{Structuring Factors}

To begin with, I lay out a series of underlying factors within the Arsakid economy that underpinned the course of internal development and change. These are (1) its fundamental agricultural base; (2) the nature of cities and urbanization; and (3) its military structure, and the related issue of elite communities.

In contrast to the Hellenistic world, neither the massive intensification of urbanism nor the overwhelming growth of the army can be conclusively, compellingly demonstrated in the case of the Arsakid world as a whole, such that proving the interlocking intensification and integration seen in Graeco-Macedonian contexts remains elusive. We start, nevertheless, with the question of agriculture, and work from there toward a discussion of possible intensification and growth. The further purpose of this agricultural starting point is to highlight the reality that, despite the considerable interest in the involvement of the Arsakid Empire with long-distance trade and the revenue that was doubtless raised by taxing this trade, ${ }^{8}$ the wealth of the Arsakid Empire was, along with the Seleukid Empire, based fundamentally on an agrarian economy. ${ }^{9}$

The amount of revenue that the Arsakid kings could extract from agrarian spaces depended on the amount of land they controlled, the productivity of that land, and the tax or tribute regimes which they employed. ${ }^{10}$ While we are able to speak

\footnotetext{
8 As pointed out in Taasob, ch. 8.B, this vol., beyond the thin evidence for this taxation, it is also unclear whether it was, in fact, being collected and put to use on an imperial rather than local level; see particularly the recent argument in Hartmann 2018.

9 There is little synthetic work on agricultural regimes in the Arsakid Empire, outside of archaeological treatments of Babylonia and Susiana, on which see respectively Adams 1962; 1965; 2006; and Wenke 1976.

10 On estimates of productivity in the case of Mesopotamia, Jursa 2010. For an overview of tax regimes, see Taasob, ch. 8.B, II, this volume.
} 
about the first factor with some precision, our ability to generalize about the second two is far more limited because of the evidentiary issues raised in the introduction. It is nevertheless possible to make a few broad statements about the economic role that agriculture, pastoralism, and changes in patterns of cultivation (both through conquest and intensification) played in the Arsakid world. Firstly, the expansion of the Arsakid Empire into Mesopotamia and Babylonia in the mid-second century BCE brought vast productive territories into Arsakid hands. The earlier first millennium BCE cultivation regimes of some of these lands, and the potentially high yields, are fairly well documented, giving us a good sense of the raw economic value of this land. ${ }^{11}$ Furthermore, and pointing toward explicit interest in expanding agricultural potential, evidence for the expansion of irrigation systems and the resultant growth in settlement density in southern Mesopotamia suggest that the trajectory of increasing investment in agricultural systems, visible also under the Seleukids, continued under the Arsakids. ${ }^{12}$ Finally, among the relatively scant documentary evidence explicitly related to economic activity, it is interesting to note the prominence of viticulture, which is central to the transactions recorded in both the Avroman documents and particularly the Nisa ostraca, which attest to the production and storage of vast amounts of wine within an explicitly administrative context. ${ }^{13}$ The tax records preserved on the Nisa ostraca furthermore reveal the involved nature of land taxation in conjunction with this royal precinct. ${ }^{14}$ The vocabulary of the ostraca point to a significant continuation of Achaemenid land classification terms, such that the underlying logic of the taxation regimes at this new Arsakid capital rests on older (and non-Graeco-Macedonian) patterns.

Beyond the cultivation of cereal crops like barley, wheat, and even rice, ${ }^{15}$ as well as viticulture, pastoralism was also widely practiced at multiple scales and in various configurations across the Arsakid Empire. ${ }^{16}$ Of particular interest from the point of view of economic connectivity is doubtless the specialized horse breeding that is associated with the Iranian world broadly speaking, and with the Parthian homeland in northwestern Iran particularly. ${ }^{17}$ Moreover, according to Chinese sources, the Anxi were well known for their export of horses, likely the so-called Nisaean breed, famous for its enormous size and strength. ${ }^{18}$ Although the economic role of the horse is difficult to fully explicate, beyond the horses themselves, there also

11 Particularly in Babylonia, on which, Jursa 2010.

12 Neely and Wright 1994; Adams 1965; Taasob, ch. 8.B, IV, this volume.

13 E.g., as described by Lippolis and Manassero 2015, esp. 130-131.

14 E.g., the sample published by Weber in Hackl, Jacobs and Weber 2010, 2:502-556. Main publication in Diakonoff and Livshits 1976-2001

15 On rice in Elam, Potts 1991.

16 On the basis, at least, of ethnographic models for the various types of pastoralism supported in these landscapes: Abdi 2003; Gilbert 1983; Potts 2014.

17 Shahbazi 1987.

18 Shiji 123.3161. 
appear to have been specialized industries that produced the rich alfalfa fodder known to be used by horse-breeders, the seeds of which spread through Central Asia to China. ${ }^{19}$ The broader industry of horse production, involving both agriculturalists and pastoralists, was therefore important to both internal security - in that horses formed a central part of Arsakid armies - and likely international trade.

Although the immensely fertile territories of Mesopotamia were critical to Arsakid imperial geography, the dynasts also expanded their power into a halo of regions incorporated as vassal states and ruled indirectly, from the South Caucasus to Arabia, which also of course expanded their tributary base. The general Arsakid policy of ruling much of this territory through vassal intermediaries would have removed much of the need for a centralized bureaucratic class serving as tax agents across the sprawling, rugged territories. But it also limited the Arsakid ability, and likely their interest, in interfering with local production systems, which may account for the uneven indications of processes like agricultural intensification across the space.

The second structuring factor, intrinsically entwined with agricultural production, is urbanism. Here, the nature of Arsakid urban structure raises interesting questions with respect to the growth trajectory laid out by von Reden. On the one hand, the Arsakid Empire included a great number of cities. In the Chinese tradition, the Arsakid Empire (Anxi) was strongly associated with an urbanized landscape, said to contain "hundreds" of cities. ${ }^{20}$ The building activities of Arsakid dynasts themselves display an interest in the vocabulary of urbanism, seen through the construction and dedication of a string of royal capitals starting at Nisa and ending at Ktesiphon. Beyond the physical expansions of the new Arsakid city at Seleukeia-Ktesiphon, ${ }^{21}$ there is also evidence of impressive growth at some other older urban sites under the Arsakids, with that from Susa painting such a picture. ${ }^{22}$ On the basis of archeological research, urban populations in this region - as well as some others in the Arsakid world - reached significant heights in this period. ${ }^{23}$ And yet, in contrast to either their Seleukid predecessors or their Sasanian successors, the number of Arsakid royal urban foundations appears to have been fairly limited, at least as far as are attested in literature. ${ }^{24}$ This may be in part a product of the already-dense urban landscape that the Arsakids encountered as they moved from their original northern center to the west and eventually into Mesopotamian under Mithridates I. Here, they came to occupy territory that had very ancient urban sys-

19 See also Morris, ch. 4, VII.1.2, this volume.

20 Hou Hanshu 96A; Shiji 125; trans. Watson 1993, 268.

21 For a summary of research, Kröger 1993.

22 Martinez-Sève 2015.

23 See however Rezakhani 2015, esp. 96-98, with a discussion of Khuzistan and Tokharistan/ Bactria in the Sasanian period with reference to earlier developments, which points out the challenges with the narratives of Late Antique decline

24 Chaumont 1973; 1974. 
tems, which had seen significant urbanization under the Seleukids. The question of precisely what role centrally directed planning played in the growth of these already-urbanized spaces is unclear. Detail surrounding the management of the nexus of Susa/Seleukeia-Eulaios/Phraata and its hinterland, for example, make clear the role that local officials played in creating the conditions for local agricultural prosperity - but one cannot dismiss the interlocking local and imperial engagements at Susa. ${ }^{25}$

Arsakid urban spaces were also, of course, market hubs. Although evidence for marketing activity is scarce, Babylonian sources detail with considerable exactitude the presence of a commodities market for agricultural products, as well as the significant fluctuation of prices on this market in the Arsakid period. ${ }^{26}$ It is worth noting that one of the largest institutional actors of the Arsakid period - temples, who themselves were fundamental landholders - also purchased foodstuffs on this market. ${ }^{27}$ Thus, we catch a small glimpse of the presence of robust market structures, even if we should assume that they were both local and variable in scale across Arsakid space. A final factor worth mentioning in conjunction with urbanism is that of craft production in urban contexts. As research on the material from the capital of Nisa has demonstrated, the city was the home to a vibrant artistic tradition that produced works in a distinctive style that, while recognizable as part of the broader 'Hellenistic' tradition, owes much to local ingenuity. ${ }^{28}$ Craft production (likely urban), both of elite goods like metalwork and more quotidian products like glass, was a feature of centers across the later Sasanian Empire. ${ }^{29}$ Although the archaeological evidence for such vibrant production systems is largely absent for the Arsakid period, we should expect that Arsakid cities were also themselves productive hubs, if not at the same scale.

The final structuring factor in this discussion is the Arsakid army. Contentious details surrounding the nature of the Arsakid army notwithstanding - the existence and size of the standing army, the degree of centralized control over the forces, the role of mobile pastoralists, and so on ${ }^{30}$ - the broad picture that emerges is of a largely nonprofessional army raised directly by the kings and levied from the noble families or wuzurgān, supplemented by mercenaries hired particularly from the pastoralist communities on the north and northwestern fringes of the empire, and supported by a smaller contingent of garrisoned soldiers. ${ }^{31}$ On the surface, it is difficult to argue that the Arsakid army was as central an economic factor as those of the

25 See discussion in Taasob, ch. 8.B, V.I, this volume.

26 Data from the Astronomical Diaries, see analysis in van der Spek 2014.

27 As evidenced in the Rahīm-Esu archive, van der Spek 1998.

28 Jacobs in Hackl, Jacobs, and Weber 2010, 1:129-135; Invernizzi and Lippolis 2008.

29 See, e.g., Simpson 2015 on regional glass production at the northwestern fringes of Sasanian space.

30 Hauser 2006. See also Fabian, vol. 1, ch. 6, III.2.

31 Olbrycht 2016 for one discussion of the composition of the army in more detail. 
Hellenistic kingdoms described by von Reden - for one thing, the overall scale of the army was simply smaller, as were outlays on military infrastructure. ${ }^{32}$ And yet, as discussed below, it is a mistake to overlook the comparison too quickly.

First, the direct costs of maintaining the army and paying merceries may indeed have had an impact on coin production, and by extension monetization, across the Arsakid space in at least some moments. ${ }^{33}$ But the evidence for the scale of this impact is limited, such that coinage production cannot be explained by this mechanism alone. ${ }^{34}$ More interestingly, the structure of the armed forces and the heavy reliance on the levying of troops from among elite Parthians and local rulers - who controlled their fighters and could put them to use not only in the service of the King of Kings, but also for their own purposes ${ }^{35}$ - is a key structural characteristic of the political organization of the Arsakid Empire. Over time, this organizational structure created a distinct set of pressures on Arsakid kings that, as discussed below (sec. III), shaped patterns of connectivity with economic consequences.

The three broad structuring factors serve as the framework and background for the rest of this discussion, which concerns itself with identifying particular characteristics of Arsakid sociopolitical structures that, on the one hand, help us to understand patterns of development in the space, and on the other, lead to the creation of an expansive network that was nevertheless unique in comparison to those that had or were developing in neighboring empires.

\section{Threads of Transformation}

It is by now itself a truism to note that Arsakid history should not be understood as a history of decline in the context of a weak imperial framework. Phenomena that were once interpreted as incomplete or failed realizations of Seleukid patterns are being reevaluated in terms of their potential functions within the new Arsakid order, as well as in light of their durability and the flexibility they allowed the Arsakid dynasts. In some cases, the transformations discussed here are fundamental differences that set the Arsakids apart from their predecessors: new sociopolitical or socioeconomic models that they carried with them from their early days through their rise into a major world power. In other cases, they are transformations that unfolded over the course of Arsakid history, reflecting reactions to changing circumstances.

32 See scale estimates in Overtoom 2020, passim.

33 E.g., de Callataÿ 1994 on seasonal patterns of minting under Phraates IV that suggest military rhythms. But, see in general the complications surrounding Parthian coinage, debasement, and its connection to military payments introduced by Sinisi 2018, 487-490, cf. Keall 1975.

34 Sinisi 2018, 487-490.

35 Dąbrowa 2013, 56. 
First, we begin where we left off in the last section with the question of the military, and the transformations that Arsakid-style armies brought with them. As the Parni conquered their way west, they brought with them a new military order, based largely on mounted warriors, in which a relatively small number of noble houses and important vassals served as key intermediaries. This system, and particularly the dependence on calvary, was not simply a holdover from the Parni's own putatively pastoralist lifeways, but was instead honed over the course of Arsakid history, as the empire faced nearly continuous pressure from similarly organized and armed opponents on their eastern front. ${ }^{36}$ The effective system required less investment in the heavy machinery of siege warfare or in the naval military infrastructure than strategies that were pursued by western neighbors, ${ }^{37}$ although spending on mercenaries could nevertheless be a considerable burden at times.

The reliance on forces levied from the noble families was a result of the decentralized nature of Arsakid power. But it also reinforced it by empowering these families, and thus ensuring that they retained considerable independence. ${ }^{38}$ Speaking of stability, it is worth noting the longevity of these intermediaries, with some Parthian families attested as key political actors under both the Arsakid and subsequent Sasanian dynasties. ${ }^{39}$ This structure is in keeping with the larger trope inside of the Arsakid world of uneven integration despite considerable interaction. Thinking about the institutional characteristics of the military, the decentralized structure and reliance on levied troops reduced function of the military as a vehicle for crossfertilization in the form of long-distance networking and standardization on either a private or public level. It also vastly diminished the role of veterans in comparison to the Hellenistic kingdoms (or the Roman Empire), where they formed a potent force shaping both demographic patterns and land tenure regimes. ${ }^{40}$ At the same time, the reliance on a dependable and widespread access to horses was a key ingredient in the maintenance of Arsakid political power, which may well have stimulated the expansion of the important horse-breeding tradition discussed above. ${ }^{41}$

A different sphere in which notable transformation and innovation between Seleukid and Arsakid models can be seen is in the domain of coinage. As recently

36 Overtoom 2020, 27-64.

37 Which is not to say that there were not technological innovations in calvary-based warfare, but only that they did not have the broad-reaching infrastructural and technological consequences of practices in the Seleukid world.

38 For this in the classical tradition, Plutarch Crassus 21. 6, on the Parthian noble Sūren, about whom it was said "in wealth, birth, and consideration, he stood next the king."

39 Pourshariati 2008, 49-51 on key Parthian houses that lived on in the Sasanian period; e.g., 5566 on the Sūren family.

40 Compare to Fabian and Weaverdyck, ch. 3.A, IV.3, this volume.

41 For a recent overview of the role of horses in Arsakid military contexts and bibliography on the debates surrounding the role of horse-culture in the Arsakid Empire, see Overtoom 2020, 30-31, 38-40. 
discussed synthetically by Sinisi, the Arsakid system developed and diverged significantly from the Seleukid patterns that undergirded the currency and its production in terms of both its denomination system and the mint networks that produced it. ${ }^{42}$ The denomination system of Arsakid coinage came to be based on the drachm, despite the continued, if restricted, minting of heavier-weight tetradrachms, with bronze circulating in some cases on a regional level. Furthermore, the networks of mints that produced this coinage both extended far to the east of earlier Seleukid mints, and over time developed specific internal nodes for the production of particular denominations, particularly Seleukia for tetradrachms and Ekbatana (among several others) for drachms. ${ }^{43}$ The concentration of many of the mints to the east of Mesopotamia, along a major northern east-west axis (the so-called Great Khoresan road), is one indication of the dramatic shifts in imperial geography and in the center of balance between the Seleukid and Arsakid worlds. ${ }^{44}$

In fleshing out the evidence for the use of silver more broadly in the economy of the Arsakid world, Canepa has recently discussed some evidence that places silver vessels as an entwined and entangled component of the Arsakid monetary system. ${ }^{45}$ As in the Mediterranean, silver plate in southwest Asia and Iran functioned both as a prestige gift and as a way of transferring large amounts of value between individuals, for example in the context of diplomatic relationships. One characteristic that may set the Arsakid silver vessels apart, in the model proposed by Canepa and based an analysis of vessel weights and inscriptions, is that the weights of the vessels appear not to have been recorded according to normalized weights, but rather calculated on the basis of actual, contemporary circulating coinage, meaning that there were direct equivalencies between elite silver plate and coinage. ${ }^{46}$ This hints at a regime of value within the Arsakid space that united coinage and prestige objects within a single conceptual system, which should be understood as distinct from the operating norms within Hellenistic or Roman spaces. Furthermore, the formulae used in bureaucratic inscriptions recording the transfer of one such vessel from a private individual to what seems to be an imperial treasury echoes the language of transfer of agricultural products known from the Nisa ostraca. ${ }^{47}$ This connects this elite vessel with a wider - and possibly geographically extensive ${ }^{48}$ - system of administrative records of payments to the state, formulated in standard language across a range of classes of material objects.

Beyond monetary systems and beyond the issues raised in chapters 3.B and 8.B, there is some additional evidence for concrete institutional change in some territo-

42 Sinisi 2018.

43 Sinisi 2018; also Taasob, ch. 8.B, III, this volume.

44 On this route in Arsakid contexts, Daryaee 2020.

45 Canepa 2021; Vickers 1995.

46 Canepa 2021, 19-21.

47 Canepa 2021, 14.

48 The findspot of the rhyton is unknown. 
ries brought under Arsakid control in the period - particularly spaces that had been only precariously incorporated into the Hellenistic world. There is, for example, both textual and archaeological material from the South Caucasus that points to the adoption of Arsakid administrative logics. ${ }^{49}$ The most explicit material evidence that points to the wider adoption of new administrative frameworks in this region comes from several caches of bullae that have been found both in the territory of Armenia and Caucasian Albania. ${ }^{50}$ Although the practice of using bullae in accounting is far older than the Arsakid Empire, evidence of such practices is thin in the South Caucasus before the first century BCE - when the territory came into the Arsakid orbit. Subsequently, we find strong parallels between seals and sealing practices in both public and private contexts in the South Caucasus and those known from Nisa, as well as several other sites under Arsakid control, and from the broader Mesopotamian world. ${ }^{51}$

But the adoption of these practices was neither even nor consistent - or put differently, there does not appear to have been a set 'package' of Arsakid institutional norms that moved with the expansion of the empire. Even something as basic as urban networks do not seem to have spread evenly in all parts of the Arsakid world: evidence of urban intensification in the crucial territory of Armenia is, for example, difficult to pinpoint. It is possible that this and related absences may have to do with the variable scale and priority of archaeological work across spaces held by the Arsakids. But it is also possible that, unlike their Sasanian successors who were extremely active in city foundations and refoundations, this type of self-conscious, widespread urbanism was not as central to the priorities of Parthian dynasts, and therefore was only carried out within local contexts where it dovetailed with other long-standing developmental trends, as the evidence from Mesopotamia suggests.

Considering centrally directed fiscal management more specifically, it is difficult to find widespread evidence for fundamental institutional change under the Arsakids of the type noted by von Reden in the Hellenistic period. The evidence from urban and temple contexts discussed by Taasob in chapter 3.B suggests on the whole a minimally invasive Arsakid administrative approach, wherein preexisting structures were largely accommodated. However, and in contrast to the Hellenistic world where we can track the differential treatment of constituent components in royal systems, we do not know enough about the terms on which independence

49 The textual evidence is indirect, and stems from later remembrances of the pre-Christian period in the local historical tradition, on which in general see particularly Rapp 2009; 2014, esp. 205-227. See also e.g., the presence of religious structures in the South Caucasus with likely Iranian connections, K'imšiašvili and Narimanišvili 1995.

50 Armenia: Khachatrian 1996; Manoukian 1996; Caucasian Albania: Khalilov and Babaev 1974.

51 On seals and sealing practices at Nisa, Masson and Pugacenkova 1954; Lippolis and Manassero 2015. For evidence from the sites of Qumis and Göbekly-Depe, see respectively Gibson 1994 and Koshelenko 1996. 
was negotiated in the Arsakid space to enable us to fully understand the system. ${ }^{52}$ In looking at the limited evidence we have, chiefly from Dura-Europos, we find moments that suggest more direct intervention aimed at capturing (diverse) local communities within the fiscal network of the Arsakids, but within constructs that would have been locally legible as well. ${ }^{53}$ The tendency toward the concentration of official roles within a small number of families that has been witnessed by the first century CE at Dura, ${ }^{54}$ furthermore, suggests a trend toward the consolidation of power in the Arsakid space that is reminiscent of the consolidation of military power in the hands of the wuzurgān.

The installation of Parthian elites on the thrones of vassal states represents a particularly high-level version of this strategy of consolidation that, although often directly connected to political or military concerns, also had meaningful consequences for the ability of the Arsakids to capture revenue from these spaces. The particular activity and interference of the Arsakids in the affairs of their southern vassals in Charakene are particularly suggestive in this context, given the critical role of this space in the intersection of land-based and maritime trade routes. ${ }^{55}$ An analysis of the development of the political status of Charakene over time demonstrates perfectly the movement from an independent vassal kingdom with wide-reaching rights including coining its own money in the late second century $\mathrm{BCE},{ }^{56}$ to a territory ruled directly a member of the Arsakid royal family by the beginning of the second century CE, following the ready submission of the local dynast Attambelos VII to the Roman emperor Trajan..$^{57}$

The three threads of transformation discussed above clarify particular spheres in which Arsakid sociopolitical practices developed and came to reshape a large part of southwestern Asia into a particularly flexible imperial system under their control. It is true, of course, that there were deep continuities of institutional behavior from the Seleukid period in many realms, but the sum total of the imperial system was something entirely new.

\section{Conclusion: Networking Forces}

In thinking about the components of this system, we find core territories with their mixture of Parthian elite families and non-Parthian (often, but not always, Greek)

52 Consider for example the complex relationships between 'Greek' urbanites and Arsakid kings that underpin relationships in Mesopotamian cities, Wiesehöfer 2015.

53 See for example Manesos the arabarchos named in P. Dura 20, possibly with oversight over nonsedentary communities. Sommer 2004, 163; and Taasob, ch. 3.B, II, this volume.

54 Gregoratti 2016, 27.

55 Hauser forthcoming on Spasinou Charax; Gregoratti 2019 on Parthian interests in Indian Ocean trade.

56 Sellwood 1983, 310-314.

57 Cassius Dio 68. 28. 4. Schuol 2000, 344-348; Gregoratti 2017 for an arc of development. 
elites, particularly in the cities of Mesopotamia. Then we have the vassal polities, which became entwined and remained entangled with the Arsakid dynasts through a combination of marriage politics, institutional arrangements, and armed conflict. ${ }^{58}$ And beyond them, we must also add the many local communities that integrated themselves at least in part within Arsakid administrative structures. We see such integration in the accounts in Palmyrene caravan inscriptions, where Palmyrene individuals held official roles in Arsakid cities important to Palmyrene trade. ${ }^{59}$ We should assume that the Palmyrenes were not an exception, but rather suggestive of types of networks that would have made the edges of Arsakid control porous.

Understanding the changes that came to economic life under the Arsakids requires an appreciation of how these new networks replaced Seleukid patterns. First, despite the importance of Mesopotamia and its agricultural riches, the Arsakid dynasts were at home in the vast uplands of Iran in a way that the Graeco-Macedonian rulers had never been, with even their mint networks reflecting this orientation. Second, they expanded their sphere of influence more solidly than the Successors had managed into spaces like the South Caucasus, gaining a foothold in Armenia, vexing the Roman Empire for centuries, but also maintaining much closer ties with a range of pastoralist neighbors to the north and east of their territory. Third, they pursued a diverse range of strategies for their involvement in the southern reaches of their territory, where they interfaced with Indian Ocean trading routes, particularly as tensions with Rome flared in the second century CE.

But at the same time, and despite this obvious change in imperial geography, the transmission of a clear-cut package of cultural or economic behaviors is not apparent. To consider just one small point: whereas the settlement of veterans from Hellenistic armies created wide webs of either ethnic or cultural Greekness in the Hellenistic world, the Arsakid world saw the emergence of a much smaller network of military-aristocratic leaders who were linked across great spaces by very close and intense ties. Furthermore, when speaking of the logic of control in Arsakid space, Kaizer has recently pointed out that "indirect control - through 'minor' kings as at Hatra, through communities such as those of the Jews, and through cities like Susa (Seleucia-ad-Eulaeum) - was the norm, not the neat provincial structure as we know it from Rome. And being part of the Arsakid realm did not mean continuously belonging to it in equal measure."60

The result of all of this is an empire that is something of a chameleon: its own official apparatus as evinced through things like monetary policy or administrative infrastructure, although present to some degree, blends in with the background norms of each different space in the larger, composite whole. The scope of standardization in the sense of Grewal appears in many ways more limited than in other

58 On family links, Dąbrowa 2018.

59 See also the discussion in von Reden, ch. 2, this volume.

60 Kaizer 2017, 68. 
empires discussed in this volume, with critical axes of institutional, social, and economic norms varying tremendously across the space. And yet, precisely that variability may have provided some specific advantages in that it allowed for the maintenance and expansion of locally suitable regional economic systems, linked together and made legible through the intense interpersonal aristocratic and elite networks that swirled around Arsakid dynasts.

\section{References}

Abdi, K. 2003. "The early development of pastoralism in the Central Zagros mountains." Journal of World Prehistory 17.4, 395-448.

Adams, R. M. 1962. "Agriculture and urban life in early southwestern Iran." Science 136.3511, 109-122.

-. 1965. Land behind Baghdad: A history of settlement on the Diyala plains. Chicago, IL: University of Chicago Press.

-. 2006. "Intensified large-scale irrigation as an aspect of imperial policy. Strategies of statecraft on the late Sasanian Mesopotamian plain." In J. Marcus and D. Stanish (eds.), Agricultural strategies, 17-37. Los Angeles, CA: Cotsen Institute of Archaeology.

Canepa, M. P. 2021. "The Getty stag rhyton and Parthian aristocratic culture: New epigraphic and technical discoveries." Getty Research Journal 13.1, 1-30.

Chaumont, M.-L. 1973. "Études d'histoire parthe. II: Capitales et résidences des premiers Arsacides (IIle-ler s. av. J.-C.)." Syria 50, 197-222.

-. 1974. "Études d'histoire Parthe. III: Les villes fondées par les Vologèse." Syria 51, 75-89.

Dąbrowa, E. 1998. "Philhellên: Mithridate ler et les Grecs.” In E. Dąbrowa (ed.), Ancient Iran and the Mediterranean world: Proceedings of an international conference in honour of Professor Józef Wolski held at the Jagiellonian University, Cracow, in September 1996, 9-17. Krakow: Jagiellonian University Press.

-. 2013. "The Parthian aristocracy: Its social position and political activity." Parthica 15, 53-62.

-. 2018. "Arsacid dynastic marriages." Electrum. Studia z historii starożytnej 25, 73-83.

Daryaee, T. 2020. "Arsacid economic activity on the Silk Road." In J. D. Lerner and Y. Shi (eds.), Silk Roads: From local realities to global narratives, 215-221. Oxford: Oxbow Books.

de Callataÿ, F. 1994. Les tétradrachmes d'Orodès II et de Phraate IV. Etude du rythme de leur production à la lumière d'une grosse trouvaille. Paris: Association pour l'avancement des études iraniennes.

de Jong, A. 2013. "Hatra and the Parthian Commonwealth." In L. Dirven (ed.), Hatra: Politics culture and religion between Parthia and Rome, 143-160. Stuttgart: Franz Steiner.

Diakonoff, I. M. and V. A. Livshits. 1976-2001. Parthian economic documents from Nisa.

D. N. MacKenzie, A. N. Bader, and N. Sims-Williams (eds.). 6 vols. London: School of Oriental and Asian Studies.

Gibson, M. 1994. "Parthian seal style: A contribution from Nippur." Mesopotamia 29, 89-105.

Gilbert, A. S. 1983. "On the origins of specialized nomadic pastoralism in western Iran." World Archaeology 15.1, 105-119.

Gregoratti, L. 2016. “Dura-Europos: A Greek town of the Parthian Empire.” In T. Kaizer (ed.), Religion, society and culture at Dura-Europos, 16-30. Cambridge: Cambridge University Press.

-. 2017. "Sinews of the other empire: The Parthian Great King's rule over vassal kingdoms." In

H. Teigon and E. Seland (eds.), Sinews of empire, 95-104. Oxford: Oxbow.

-. 2019. "Indian Ocean trade: The role of Parthia." In M. A. Cobb (ed.), The Indian Ocean trade in antiquity: Political, cultural and economic impacts, 52-72. London: Routledge. 
Hackl, U., B. Jacobs, and D. Weber (2010), Quellen zur Geschichte des Partherreichs Textsammlung mit Übersetzungen und Kommentaren, 3 Vols. Göttingen: Vandenhoeck \& Ruprecht.

Hartmann, U. 2018. "Wege durch Parthien - Straßen, Handelsrouten und Kommunikation im Arsakidenreich." In B. Woytek (ed.), Infrastructure and distribution in ancient economies, 2831. Vienna: Verlag der Österreichischen Akademie der Wissenschaften.

Hauser, S. R. 2005. "Die ewigen Nomaden? Bemerkungen zu Herkunft, Militär, Staatsaufbau und nomadischen Traditionen." In B. Meißner, O. Schmitt, and M. Sommer (eds.), Krieg Gesellschaft - Institutionen: Beiträge zu einer vergleichenden Kriegsgeschichte, 163-208. Berlin: Akademie-Verlag.

-. 2006. "Was there no paid standing army?: A fresh look on military and political institutions in the Arsacid Empire." In M. Mode and J. Tubach (eds.), Arms and armour as indicators of cultural transfer: The steppes and the ancient world from Hellenistic times to the early Middle Ages, 295-319. Wiesbaden: Reichert.

-. Forthcoming. "The Arsacid centre of trade: Charax Spasinou, capital of Mesene." In M. Dwivedi, L. Fabian, K. Leese-Messing, L. Morris, and E. J. S. Weaverdyck (eds.), Economies of the edge. Frontier zone processes at regional, imperial, and global scales (300 BCE-300 CE).

Invernizzi, A. and C. Lippolis, eds. 2008. Nisa Partica. Ricerche nel complesso monumentale arsacide 1990-2006. Florence: Le lettere.

Jursa, M. 2010. Aspects of the economic history of Babylonia in the first millennium BC: Economic geography, economic mentalities, agriculture, the use of money and the problem of economic growth. Munich: Ugarit-Verlag.

Kaizer, T. 2017. "Empire, community, and culture on the Middle Euphrates. Durenes, Palmyrenes, villagers, and soldiers." Bulletin of the Institute of Classical Studies 60.1, 63-95.

Keall, E. J. 1975. "Parthian Nippur and Vologases' southern strategy: A hypothesis." Journal of the American Oriental Society 95.4, 620-632.

Khachatrian, Z. 1996. "The archives of sealings found at Artashat (Artaxata)." In M.-F. Boussac and A. Invernizzi (eds.), Archives et sceaux du monde hellénistique / Archivi e sitilli nel mondo ellenistico. Supplement, Bulletin de correspondence hellénique no. 29, 365-370.

Khalilov, Dzh. A. and I. A. Babaev. 1974. “О городах Кавказской Албании” [On the Cities of Caucasian Albania]. Советская археология, no. 4: 197-209.

K'imšiašvili, K. and G. Narimanišvili. 1995. "A group of Iberian fire-temples (4th cent BC2nd cent AD)." Archäologische Mitteilungen aus Iran und Turan 28, 309-318.

Koshelenko, G. A. 1996. "Bullae from Göbekly-Depe: General problems and main subjects." In M. F. Boussac and A. Invernizzi (eds.), Archives et sceaux du monde hellénistique/Archivi e sitilli nel mondo ellenistico. Supplement, Bulletin de correspondence hellénique no. 29, 376383.

Kröger, J. 1993. "Ctesiphon.” In Encyclopaedia Iranica. Vol. 6.4, 446-448. Available online at http://www.iranicaonline.org/articles/ctesiphon.

Lippolis, C. and N. Manassero. 2015. "Storehouses and storage practices in Old Nisa (Turkmenistan)." Electrum. Studia z historii starożytnej 22, 115-142.

Lukonin, V. G. 1983. "Political, social and administrative institutions: Taxes and trade." In E. Yarshater (ed.), The Cambridge history of Iran. Vol. 3.2, 681-746. Cambridge: Cambridge University Press.

Manoukian, H. 1996. "Les empreintes d'Artachate (Antique Artaxata)." In M.-F. Boussac and A. Invernizzi (eds.), Archives et sceaux du monde hellénistiqu/Archivi e sitilli nel mondo ellenistico. Supplement, Bulletin de correspondence hellénique no. 29, 371-373.

Martinez-Sève, L. 2015. "Susa iv. The Hellenistic and Parthian periods." In Encyclopaedia Iranica, online edition. http://www.iranicaonline.org/articles/susa-iv-hellenistic-parthian-periods.

Masson, M. E. and G. A. Pugacenkova. 1954. “Оттиски парфянских печатей из Нисы” [Impressions of Parthian Seals from Nisa]. Вестник древней истории, nо. 4, 159-169. 
Neely, J. A. and H. T. Wright. 1994. Early settlement and irrigation on the Deh Luran Plain: Village and early state societies in southwestern Iran. Ann Arbor, MI: University of Michigan Museum of Anthropology.

Olbrycht, M. J. 2003. "Parthia and nomads of Central Asia. Elements of steppe origin in the social and military developments of Arsacid Iran." I. Schneider (ed.) Mitteilungen des SFB "Differenz und Integration". Vol. 5, 69-109.

-. 2013. "The titulature of Arsaces I, King of Parthia." Parthica 15, 63-74.

-. 2015. "Arsacid Iran and the nomads of Central Asia - ways of cultural transfer." In J. Bemmann and M. Schmauder (eds.), Complexity of interaction along the Eurasian steppe zone in the first millennium, 333-390. Bonn: Vor- und Frühgeschichtliche Archäologie, Rheinische Friedrich-Wilhelms-Universität Bonn.

-. 2016. "Manpower resources and army organisation in the Arsakid empire." Ancient Society 46, 291-338.

-. 2019. “The Aparnoi in the Arsacid history.” In В. А. Алёкшин, Л. Б. Кирчо (eds.) Древности Восточной Европы, Центральной Азии и Южной Сибири в контексте связей и взаимодействий в евразийском культурном пространстве (новые данные и концепции). Vol. 1, 161-165. Санкт-Петербург: Институт истории материальной культуры РАН; Невская Типография.

Overtoom, N. L. 2020. Reign of arrows: The rise of the Parthian Empire in the Hellenistic Middle East. New York, NY: Oxford University Press.

Pirngruber, R. 2017. The economy of Late Achaemenid and Seleucid Babylonia. Cambridge: Cambridge University Press.

Potts, D. T. 1991. “A note on rice cultivation.” Nouvelles Assyriologiques Brèves et Utilitaires 1991, 2.

-. 2014. Nomadism in Iran: From antiquity to the modern era. Oxford: Oxford University Press.

Pourshariati, P. 2008. Decline and fall of the Sasanian Empire. The Sasanian-Parthian confederacy and the Arab conquest of Iran. London: I. B. Tauris.

Rapp, S. H. 2009. “The Iranian heritage of Georgia: Breathing new life into the pre-Bagratid historiographical tradition." Iranica Antiqua 44, 645-692.

-. 2014. The Sasanian world through Georgian eyes: Caucasia and the Iranian Commonwealth in Late Antique Georgian literature. Farnham: Ashgate.

Rezakhani, K. 2015. “Continuity and change in Late Antique Irān: An economic view of the Sasanians.” International Journal of the Society of Iranian Archaeologists 1.2, 93-118.

Schlude, J. M. and A. J. Overman. 2017. "Herod the Great: A Near Eastern case study in RomanParthian politics." In J. M. Schlude and B. Reubin (eds.), Arsacids, Romans and local elites: Cross-cultural interactions of the Parthian Empire, 93-110. Oxford: Oxbow Books.

Sellwood, D. 1983. “Minor states in southern Iran." In E. Yarshater (ed.), The Cambridge history of Iran. Vol. 3.1, 299-321. Cambridge: Cambridge University Press.

Shahbazi, A. Sh. 1987. “ASB i. In Pre-Islamic Iran.” In Encyclopaedia Iranica. Vol. 2.7, 724-730. Available online at http://www.iranicaonline.org/articles/asb-pre-islamic-iran.

Shayegan, M. R. 2011. Arsacids and Sasanians: Political ideology in post-Hellenistic and Late Antique Persia. Cambridge: Cambridge University Press.

Simpson, S. J. 2015. "Sasanian glassware from Mesopotamia, Gilan, and the Caucasus.” Journal of Glass Studies, 77-96.

Sinisi, F. 2018. "Some remarks on Parthian coin production.” In B. E. Woytek (ed.), Infrastructure and distribution in ancient economies, 473-496. Vienna: Österreichische Akademie der Wissenschaften.

Sommer, M. 2004. "A map of meaning: Approching cultural identities at the Middle Euphrates (1st to 3rd centuries AD)." Egitto e Vicino Oriente 27, 153-183.

van der Spek, R. J. 1998. "Cuneiform documents on Parthian history: The Rahimesu archive: Materials or the study of the standard of living." In J. Wiesehöfer (ed.), Das Partherreich und 
seine Zeugnisse / The Arsacid Empire: Sources and documentation, 205-258. Stuttgart: Franz Steiner.

-. 2014. "The volatility of prices of barley and dates in Babylon in the third and second centuries BC." In H. D. Baker and M. Jursa (eds.), Documentary sources in ancient Near Eastern and Greco-Roman economic history, 234-259. Oxford: Oxbow.

van der Spek, R. J. and B. Leeuwen. 2014. "Quantifying the integration of the Babylonian economy in the Mediterranean world using a new corpus of price data, 400-50 BCE." In F. de Callataÿ (ed.), Quantifying the Greco-Roman economy and beyond, 79-101. Bari: Edipuglia.

Vickers, M. 1995. "Metrological reflections: Attic, Hellenistic, Parthian and Sasanian gold and silver plate." Studia Iranica 24.2, 163-185.

Watson, B. 1993. Records of the Grand Historian: Han dynasty II. Revised ed. New York, NY: Columbia University Press.

Wenke, R. J. 1976. "Imperial investments and agricultural developments in Parthian and Sasanian Khuzistan, 150 BC-AD 640." Mesopotamia 10/11, 31-221.

Wiesehöfer, J. 2015. "Greek poleis in the Near East and their Parthian overlords." In A. M. Kemezis (ed.), Urban dreams and realities in antiquity: Remains and representations of the ancient city, 328-346. Leiden: Brill.

Wolski, J. 1993. L'empire des Arsacides. Leuven: Peeters. 